\title{
Hemoglobin Subunit Epsilon
}

National Cancer Institute

\section{Source}

National Cancer Institute. Hemoglobin Subunit Epsilon. NCI Thesaurus. Code C84979.

Hemog lobin subunit epsilon (147 aa, $\sim 16 \mathrm{kDa}$ ) is encoded by the human HBE1 gene. This protein plays a role in the transport of oxygen to tissues of the embryo. 